\title{
Penerapan Good School Governance (GSG) Dan Pengaruhnya Terhadap Efektifitas Pengelolaan Bantuan Operasional (BOS) Sekolah Dasar Kota Blitar
}

\author{
Hendri Susanti \\ Dinas Pendidikan Kota Blitar
}

\begin{abstract}
This study aims to determine the effect of the application of good school governance on the effectiveness of the management of elementary school operational assistance. The method used is descriptive analysis method with a quantitative approach. The sample used saturated samples by showing all treasurers of primary school operational assistance as many as 48 people, data collected by questionnaire techniques while data analysis used multiple linear regression techniques. The results showed that participation had a positive and significant effect on the effectiveness of the management of school operational assistance, transparency had a positive and significant effect on the effectiveness of the management of school operational assistance, while accountability separately did not have a positive and significant effect on the effectiveness of the management of school operational assistance but together participation, transparency and accountability have a positive and significant effect on the effectiveness of managing school operational assistance.
\end{abstract}

Keywords: good school governance, effectiveness, and school operational assistance

\section{PENDAHULUAN}

Bantuan Operasional Sekolah (BOS) merupakan konskuensi logis dari implementasi Undang-Undang No. 20 Tahun 2003 tentang Sistem Pendidikan Nasional. Undang-Undang ini memerintahkan pemerintah dan pemerintah daerah untuk menjamin setiap warga negara yang berusia 7 15 tahun wajib mengikuti pendidikan wajib belajar minimal pada pendidikan dasar tanpa dipungut biaya. Wajib belajar minimal ini merupakan tanggung jawab negara baik pada satuan pendidikan yang diselenggarakan oleh pemerintah, pemerintah daerah, dan masyarakat.

Signifikansi peran bantuan operasional sekolah tersebut, Dewi (2015) menjelaskan bahwa bantuan operasional sekolah berperan signifikan dalam penuntasan wajib belajas 9 tahun dengan indikator pencapaian angka partisipasi kasar (APK) SD dan SMP. Dengan dilaksankannya program bantuan ini APK SD mencapai $115 \%$ pada tahun 2005 dan APK SMP mencapai 98,11 \% pada tahun 2009, sehingga program wajib belajar 9 tahun telah tuntas 7 tahun lebih awal dari target diklarasi Education for All (EFA) di Dakar.

Arti penting tersebut mengharuskan pengelolaan dana bos yang efektif dan bertanggung jawab. Indawati, dkk (2017) menjelaskan bahwa Pengelolaan keuangan sekolah yang memperhatikan regulasi dan dilaksanakan secara akuntabel, transparan, dan efisien akan menciptakan Suasana sekolah yang kondusif bagi peningkatan kinerja dan kualitas sekolah. Selai itu, dapat berdampak pada peningkatan prestasi belajar siswa tanpa memperhatikan perbedaan jenis kelamin dengan mempertimbangkan perlindungan keamanan dan kesejahteraan anak, serta memperhatikan anak yang berkebutuhan khusus.

Berkenaan dengan pembiayan pendidikan, pemerintah telah mengeluarkan Peraturan Pemerintah No. 19 Tahun 2005 tentang Standar Nasional Pendidikan sebagaimana diubah dengan Peraturan Pemerintah No. 32 Tahun 2013. Dalam tataran teknis, pemerintah telah mengeluarkan Peraturan Menteri Pendidikan Nasional Nomor 69 Tahun 2009 tentang Standar Biaya Non Personalia. Kaitan dengan iuran wali murid, pemerintah menerbitkan Peraturan Menteri Pendidikan dan Kebudayaan No. 75 Tahun 2016 Tentang Komite Sekolah.

Khusus mengenai pengelololaan bantuan operasional sekolah, pemerintah telah menerbitkan peraturan menteri setiap tahun, terakhir, pemerintah menerbitkan Peraturan Menteri Pendidikan dan Kebudayaan No. 1 Tahun 2018 tentang Petunjuk Teknis Bantuan Operasional Sekolah. Dalam peraturan ini setiap sekolah mendapatkan bantuan operasional berdasarkan jumlah murid sebesar Rp. 800.000,00 perpeserta didik pertahun untuk jenjang sekolah dasar dan sebesar Rp. 1.000.000,00 perperserta didik pertahun untuk jenjang sekolah menengah pertama. 
Berdasarkan data yang dihimpun oleh Subbag Tata Usaha Dinas Pendidikan Kota Blitar, masih namapak adanya ketidakefektivan dalam proses pengelolaan bantuan operasional sekolah baik dalam perencanaan, pelaksanaan maupun pertanggungjawaban. Hal ini ditunjukkan dengan didapatnya data bahwa pada akhir tahun 2016 realisasi dana bos untuk jenjang sekolah dasar memiliki sisa dana tidak terealisasi sebesar Rp. 130.490.989,00 dan pada akhir tahun 2017 sisa dana tidak terealisasi meningkat menjadi Rp. 139.469.021,00 atau mengalami kenaikan sebesar 6,88 \%. Adapun sisa dana perkecamatan sebagaimana tertera pada tabel 1.1 berikut.

Tabel 1.1

Rekapitulasi Sisa Dana Bantuan

Operasional Sekolah Dasar

\begin{tabular}{|c|c|c|c|}
\hline \multirow{2}{*}{ No } & \multirow{2}{*}{ Kec. } & \multicolumn{2}{|c|}{ Sisa Dana Bos (Rp) } \\
\hline & & 2016 & 2017 \\
\hline 1 & $\begin{array}{l}\text { Kepanje } \\
\text { nkidul }\end{array}$ & 64.778 .334 & 56.418 .250 \\
\hline 2 & $\begin{array}{l}\text { Sananwe } \\
\tan \end{array}$ & 35.6 & 63. \\
\hline 3 & \begin{tabular}{|l} 
Sukorej \\
$\mathrm{o}$
\end{tabular} & 30.020 .456 & 19.895 .457 \\
\hline & nlah & 130.490 .989 & 139.469 .021 \\
\hline
\end{tabular}

Sumber: Subbag Keuangan Diolah

Dari tabel tersebut akan nampak jelas permasalahan yang terjadi terkait dengan pengelolaan bantuan operasional sekolah bila ditampilan dalam bentuk grafik sebagai berikut.

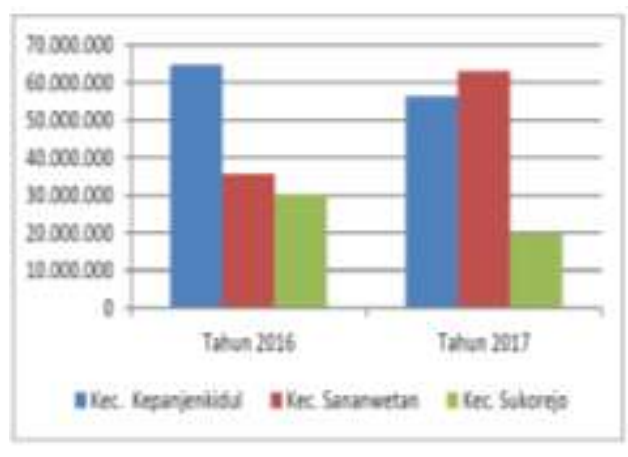

Gambar 1.1

Grafik Sisa Dana Bantuan Operasional Sekolah Dasar
Gambaran rekapitulasi sisa dana tersebut akan nampak jelas bahwa sekolah dasar di Kecamatan Sananwetan mengalami kenaikan yang signifikan dibanding dengan kecamatan yang lain bila disampaikan dalam bentuk grafik diatas. Untuk menjamin efektvitas penggunaan dana bos diperlukan manajemen pembiayaan yang tepat. Manajemen pembiayaan pendidikan harus difokuskan pada bagaimana sumber dana yang ada bisa dikelola secara profesional sehingga dapat memenuhi kebutuhan penyeleng-garan pendidikan. Jahari dan Syarbini (2013) menyatakan bahwa manajemen pembiayaan pendidikan merupakan sebuah proses dalam mengoptimalkan sumber dana yang ada, mengalokasikan dana yang tersedia, dan mendistribusikan fasilitas atau sarana pendukung pembelajaran sehingga tercipta pembelajaran yang efektif dan efisien.

Efektivitas menjadi faktor kunci keberhasilan pengelolaan dana bantuan operasional sekolah. Efektivitas merupakan sebuah pencapaian tujuan. Hambalang (2013) menyatakan bahwa efektifitas merupakan kemampuan untuk memilih cara yang tepat untuk pencapaian tujuan yang telah ditetapkan. Lebih jauh lagi, efektifitas dapat dijelaskan sebagai menumbuhkan kreatifitas (Danim, 2012). Dalam hal ini, efektifitas dapat diartikan sebagai kreatifitas sekolah dalam memilih cara yang tepat untuk mencapai tujuan sekolah.

Pencapaian tujuan sekolah harus didasarkan pada prinsip dan teori manajemen. Hal ini didasarkan pada UndangUndang No. 20 Tahun 2003 tentang Sistem Pendidikan Nasional. Ketentuan tentang Manajemen Berbasis Sekolah teruang dalam pasal 5 ayat 1 yang menyatakan bahwa pengelolaan pendidikan anak usia dini, pendidikan dasar dan pendidikan menengah dilaksanakan berdasarkan standar pelayanan minimal dengan prinsip manajemen berbasis sekolah/madrasah. Selain itu, dalam Peraturan Menteri Pendidikan dan Kebudayan Nomor 1 Tahun 2018 dijelaskan bahwa pengelolaan Bantuan Operasional Sekolah menggunakan Manajemen Berbasis Sekolah.

Pada dasarnya majemen berbasis sekolah merupakan implementasi dari Good School Governance (GSG) atau Good 
Corporate Governance (GCG) yang digunakan untuk instansi pendidikan khususnya sekolah. Good School Governance (GSG) adalah sebuah perangkat pendukung untuk membentuk sebuah sekolah dengan tata kelola yang baik. Slamet (2006) menjelaskan bahwa terdapat tiga prinsip tata kelola sekolah yang baik yaitu partisipasi, transparansi dan akuntablitas.

Berbagai penelitian telah dilakukan terkait dengan efektifitas pengelolaan dana bantuan operasional sekolah. Dewi (2015) telah membuktikan secara empiris bahwa beberapa kepala sekolah masih kesulitan dalam menyalurkan dana bantuan operasional sekolah. Lebih dalam lagi Elmizola (2015) menemukan bahwa masih adanya pengelolaan bantuan operasional yang tidak efektif disebabkan oleh ketidak sesuaian antrara perencanaan dan kebutuhan sekolah.

Berdasarkan paparan diatas maka penelitian ini memiliki tujuan untuk mengetahui :

1. Pengaruh partisipasi sekolah terhadap efektifitas pengelolaan dana bantuan operasional sekolah dasar di Kota Blitar

2. Pengaruh transparansi terhadap efektifitas pengelolaan dana bantuan operasional sekolah dasar di Kota Blitar

3. Pengaruh akuntabilitas terhadap efektifitas pengelolaan dana bantuan operasional sekolah dasar di Kota Blitar

4. Pengaruh secara bersam-sama partisipasi, transparansi, dan akuntabilitas terhadap efektifitas pengelolaan dana bantuan operasional sekolah dasar di Kota Blitar.

\section{METODE PENELITIAN}

Penelitian yang akan dilakukan tergolongan penelitian deskriptif dengan pendekatan kuantitatif.Penedekatan kuantitatif dipilih karena data yang akan didapatkan berupa angka-angka hasil isian responden terhadap quistioner yang dibagikan oleh peneliti. Sugiyono (2012:23) menjelaskan bahwa pene-litian kuantitatif adalah bila data penelitian berupa angkaangka dan analisis menggunakan statistik.

Populasi penelitian ini adalah seluruh bendahara bantuan operasional sekolah di tingkat satuan pendidikan jenjang sekolah dasar sebanyak 48 (empat puluh delapan) orang. Semua populasi dijadikan sampel penelitian sebagaimana dihelaskan oleh Arikunto (2012) yang menyatakan bahwa sampel jumlah populasi yang kurang dari 100 orang tidak perlu dilakukan sampling.

Variabel penelitian meliputi efektifitas pengelolaan bantuan operasional sebagai variabel terikat $(\mathrm{Y})$, dan prinsip-prinsip good school governance sebagai variabel bebas terdiri dari partisipasi (X1), transparansi (X2), dan akuntabilitas (X3).

Umar dan Jhones dalam Mitra (2010) 'mendefiniskan secara konseptual efektivitas didefinisikan sebagai pencapaian untuk kerja yang maksimal yaitu pencapaian target yang berkaitan dengan kualitas, kuantitas, dan waktu.Sementara itu, dalam penelitian ini efektitivitas pengelolaan bantuan operasional sekolah dapat ditinjau dari segi perencanaan, pelaksanaan dan pertanggungjawaban.

Partisipasi diartikan sebagai sebagai proses dimana stakeholders (warga sekolah dan masyarakat) terlibat aktif baik secara individual maupun kolektif secara langsung maupun tidak langsung dalam pengambilan keputusan, pembuatan kebijakan, perencanaan, pelaksanaan, pengawasan atau pengevaluasian pendidikan sekolah (Fauzan, 2014).

Trasparansi sebagai keadaan dimana setiap orang yang terkait dengan kepentingan pendidikan dapat mengetahui proses dan hasil pengambilan keputusan dan kebi-jakan sekolah. Transparansi/ ke-terbukaan ini ditunjukkan dalam dimensiinformativness, disclosure(Mardiasmo, 2006). Adapun akuntabilitas diartikan sebagai kewajiban untuk memberikan pertanggungjawaban atau untuk menjawab dan menerangkan kinerja serta tindakan penyelenggara organisasi kepada pihak yang memiliki hak atau wewenang untuk meminta keterangan atau pertang-gungjawaban Handayani (2015).

Teknik pengumpulan data menggunakan kuisioner. Jawaban responden terhadap setiap butir pernyataan pada setiap kuisioner diberikan skor sesuai dengan skala linkertyang mempunyai gradasi dari sangat postif sampai sangat negatif (Sugiyono, 2014:93). Teknik analisa data yang digunakan oleh peneliti adalah analisis regresi linier berganda dengan bantuan software spss. 
HASIL PENELITIAN

\section{Kualitas Data}

\section{Validitas Data Penelitian}

Hasil uji validitas variabel penelitian ini tampak pada menunjukkan bahwa seluruh data pada setiap butir dinyatakan valid karena seluruhsignifiksi setiap item tersebut memiliki nilaisignifikansikurangdari0.05 sebagaimana ditunjukkan pada tabel berikut.

Tabel 1.1

Validitas Efektivitas

\begin{tabular}{|c|c|c|}
\hline Butir & $\begin{array}{c}\text { Sig. (2- } \\
\text { tailed) }\end{array}$ & $\begin{array}{c}\text { Pearson } \\
\text { Correlation }\end{array}$ \\
\hline efktv_1 & 0,000 & 0,516 \\
\hline efktv_2 & 0,000 & 0,556 \\
\hline efktv_3 & 0,002 & 0,437 \\
\hline efktv_4 & 0,000 & 0,678 \\
\hline efktv_5 & 0,000 & 0,572 \\
\hline efktv_6 & 0,007 & 0,381 \\
\hline efktv_7 & 0,004 & 0,410 \\
\hline efktv_8 & 0,000 & 0,566 \\
\hline efktv_9 & 0,001 & 0,454 \\
\hline efktv_10 & 0,000 & 0,559 \\
\hline
\end{tabular}

Sumber : Data diolah, 2018

Adapun untuk validitas varibel partisipasi (X1) adalah sebagai berikut.

Tabel 1.2

Validitas Partisipasi

\begin{tabular}{|c|c|c|}
\hline Butir & $\begin{array}{c}\text { Sig. (2- } \\
\text { tailed) }\end{array}$ & $\begin{array}{c}\text { Pearson } \\
\text { Correlation }\end{array}$ \\
\hline part_1 & 0,000 & 0,727 \\
\hline part_2 & 0,000 & 0,696 \\
\hline part_3 & 0,000 & 0,718 \\
\hline part_4 & 0,000 & 0,747 \\
\hline part_5 & 0,000 & 0,640 \\
\hline part_6 & 0,000 & 0,650 \\
\hline
\end{tabular}

Sumber : Data diolah, 2018

Untuk validitas varibel transparansi (X2) adalah sebagai berikut.
Tabel 1.3

Validitas Transparansi

\begin{tabular}{|c|c|c|}
\hline Butir & $\begin{array}{c}\text { Sig. (2- } \\
\text { tailed) }\end{array}$ & $\begin{array}{c}\text { Pearson } \\
\text { Correlation }\end{array}$ \\
\hline trans_1 & 0,000 & 0,608 \\
\hline trans_2 & 0,001 & 0,474 \\
\hline trans_3 & 0,000 & 0,538 \\
\hline trans_4 & 0,010 & 0,370 \\
\hline trans_5 & 0,000 & 0,772 \\
\hline trans_6 & 0,000 & 0,812 \\
\hline trans_7 & 0,000 & 0,788 \\
\hline trans_8 & 0,000 & 0,497 \\
\hline trans_9 & 0,000 & 0,785 \\
\hline
\end{tabular}

Sumber: Data diolah, 2018

Untuk validitas varibel akuntabilitas (X3) adalah sebagai berikut.

Tabel 1.4

Validitas Akuntabilitas

\begin{tabular}{|c|c|c|}
\hline Butir & $\begin{array}{c}\text { Sig. (2- } \\
\text { tailed) }\end{array}$ & $\begin{array}{c}\text { Pearson } \\
\text { Correlation }\end{array}$ \\
\hline akntbl_1 & 0,000 & 0,608 \\
\hline akntbl_2 & 0,000 & 0,739 \\
\hline akntbl_3 & 0,000 & 0,511 \\
\hline akntbl_4 & 0,012 & 0,359 \\
\hline akntbl_5 & 0,000 & 0,766 \\
\hline akntbl_6 & 0,000 & 0,485 \\
\hline akntbl_7 & 0,000 & 0,547 \\
\hline akntbl_8 & 0,008 & 0,380 \\
\hline akntbl_9 & 0,000 & 0,552 \\
\hline akntbl_10 & 0,000 & 0,577 \\
\hline
\end{tabular}

Sumber : Data diolah, 2018

\section{Reliabilitas Data Penelitian}

Ujireliabilitasdilakukandenganuji $A \not p h a$ Cronbach..Jikanilai alpha > 0.70makareliabilitasnyamencukupi, sementarajika 0.80mensugestikanseluruh alpha

intern karenamemilikireliabilitas yang kuat Secara total, data dinyatakan reliabel karena memiliki koefesien alpha total sebesar 0,886. Sedangkan secara terpisah antar variabel memiliki hasil uji yang berbeda-beda sebagaimana tabel 4.8 berikut : 
Tabel1.4

Reliabilitas Data

\begin{tabular}{|l|l|c|}
\hline \multicolumn{1}{|c|}{ Variabel } & Nilai & $\begin{array}{c}\text { Tingkat } \\
\text { Reliabilitas }\end{array}$ \\
\hline Efektivitas & 0,879 & Kuat \\
\hline Partisipasi & 0,881 & Kuat \\
\hline Transparansi & 0,887 & Kuat \\
\hline Akutabilitas & 0,880 & Kuat \\
\hline
\end{tabular}

Sumber : Data diolah, 2018

\section{Uju Asumsi Klasik}

\section{Uji Normalitas Data}

Dalam melakukan pengujian normalitas data, peneliti menggunakan nilai absolut dari most extreme diferences yang pada uji kolomogorov smirnov sebagaimana tabel berikut.

Tabel 1.5

Hasil Uji Kolomogorov Smirnov

\begin{tabular}{|l|c|c|}
\hline \multicolumn{1}{|c|}{ Variabel } & $\begin{array}{c}\text { Absolute } \\
\text { Value }\end{array}$ & $\begin{array}{c}\text { Nilai } \\
\text { Alpha }\end{array}$ \\
\hline Efektivitas & 0,173 & 0,05 \\
\hline Partisipasi & 0,195 & 0,05 \\
\hline Transparansi & 0,234 & 0,05 \\
\hline Akutabilitas & 0,210 & 0,05 \\
\hline
\end{tabular}

Sumber : Data diolah, 2018

\section{Uji Linieritas Data}

Uji linieritas data dimaksudkan untuk mengetahui linier tidaknya hubungan masingmasing variabel. Uji linieritas data terpenuhi bila Linierity lebih kecil dari 0,05 sebagaimana tabel berikut.

Tabel 4.9

Hasil Uji Linieritas

\begin{tabular}{|l|c|c|}
\hline \multicolumn{1}{|c|}{ Variabel } & $\begin{array}{c}\text { Linierity } \\
\text { Value }\end{array}$ & $\begin{array}{c}\text { Nilai } \\
\text { Alpha }\end{array}$ \\
\hline Partisipasi & 0,000 & 0,05 \\
\hline Transparansi & 0,000 & 0,05 \\
\hline Akutabilitas & 0,001 & 0,05 \\
\hline
\end{tabular}

Sumber : Data diolah, 2018

\section{Uji Multikolinearitas}

Untuk melakukan uji ini, peneliti menggunakan nilai tolerance dan varian inflaction factor (VIF). Nilai Tolerance $<1$, dan VIF $>1$ dan $<10$. Berdasarkan hasil uji statistik diperoleh nilai sebagai berikut.
Tabel 4.10

Hasil Uji VIF dan Tolerance

\begin{tabular}{|l|c|c|}
\hline \multicolumn{1}{|c|}{ Variabel } & Tolerance & VIF \\
\hline Partisipasi &, 827 & 1,210 \\
\hline Transparansi &, 549 & 1,821 \\
\hline Akutabilitas &, 520 & 1,925 \\
\hline \multicolumn{2}{|l}{} \\
Sumber: Data
\end{tabular}

Sumber : Data diolah, 2018

Berdasarkan hasil uji asumsi klasik dinyatakan bahwa data yang dianalisa terbebas dari multikol-inieritas, normal dan linier.

\section{Deskripsi Data}

\section{Efektivitas}

Data menyatakan bahwa rata-rata responden menyatakan bahwa pengelolaan bantuan operasional sekolah dasar berada pada level sangat efektif dengan ditunjukkan nilai rata-rata sebesar 4,404. Meskipun secara umum pengelolaan bantuan operasional sekolah dasar sudah sangat efektif, namun berdasarkan kuisioner yang dibagikan masih terdapat pada item pertanyaan ke tuju dan ke sembilan.Nilai rerata untuk pertanyaansebesar ke tuju yang berbunyi laporan realisasi kegiatan tepat waktu dan tidak molor, serta sesuai dengan peruntukkannya, sedangkan item ke sembilan berbunyi tidak ditemu-kannya markup harga / anggaran dalam laporan realisasi bantuan operasional sekolah masih perlu ditingkatkan. Skor rata-rata untuk item ketuju dan sembilan sebesar 4,109 dan 4,196. Level skor antara 3,40 - 4,20 yang mengandung pengertian pada level efektif sebagaimana grafik berikut.

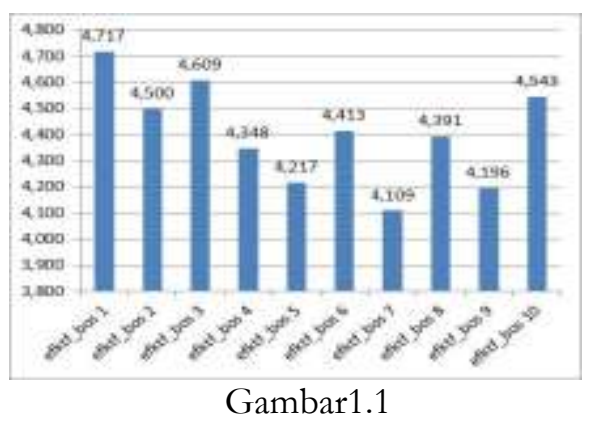

Efektivitas Pengelolaan BOS

Kota Blitar

\section{Partisipasi}

Partisipasi berada pada level sangat partisipatif. Hal ini ditunjukkan dengan perolehan skor rata-rata tanggapan 
responden terhadap variabel ini sebesar 4,243 dimana nilai rata-rata ini berada diantara 4,20 - 5,00. Meskipun dem-ikian, data juga menunjukkan adanya beberapa indikator yang berada pada posisi lebih rendah dari nilai rata-rata keseluruhan variabel ini. Responden memberikan tanggapan bahwa terkait adanya sumbangan wali murid bila biaya dari bantuan operasional sekolah tidak mencukupi mendapat-kan skor rata-rata terendah sebesar 3,609, kemudian disusul tanggapan bahwa sekolah melaksanakan survey/angket kepada pihak-pihak terkait tentang rencana dan program yang akan dituangkan dalam RAPBS mendapatkan nilai rata-rata 4,109. Gambaran secara keseluruhan nilai rata-rata pada variabel ini dapat digambarkan dalam diagram sebagai berikut.

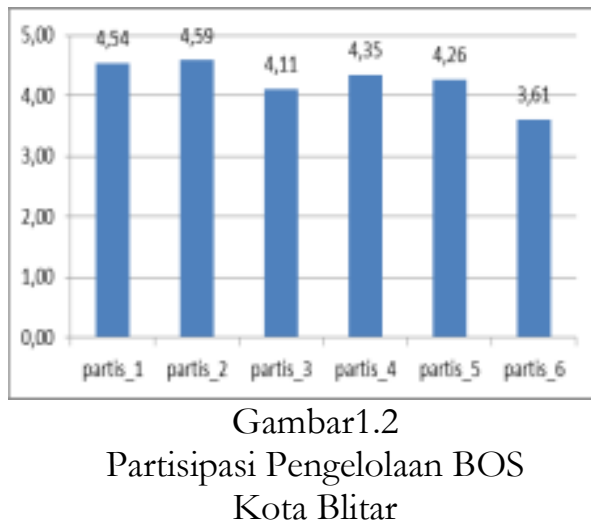

\section{Transparansi}

Transparansi berada pada level sangat transparan. Hal ini ditun-jukkan dengan perolehan skor rata-rata tanggapan responden terhadap variabel ini sebesar 4,329 dimana nilai rata-rata ini berada diantara 4,20 - 5,00. Meskipun demikian, data juga menunjukkan adanya beberapa indikator yang berada pada posisi lebih rendah dari nilai rata-rata keseluruhan variabel ini.Responden memberikan tanggapan bahwa terkait dengan peningkatan arus informasi melalui kerjasama dengan media massa oleh sekolah, kemudahan bagi setiap stakeholder memiliki akses informasi baik orang tua maupun lembaga non pemerintah, penyusunan suatu mekanisme pengaduan jika ada peraturan yang dilanggar atau permintaan untuk membayar uang suap, secara berturut-turut memiliki skor rata-rata sebesar 2.848, 4.174, dan 4.065 Gambaran secara keseluruhan nilai rata-rata pada variabel ini dapat digambarkan dalam diagram sebagai berikut.

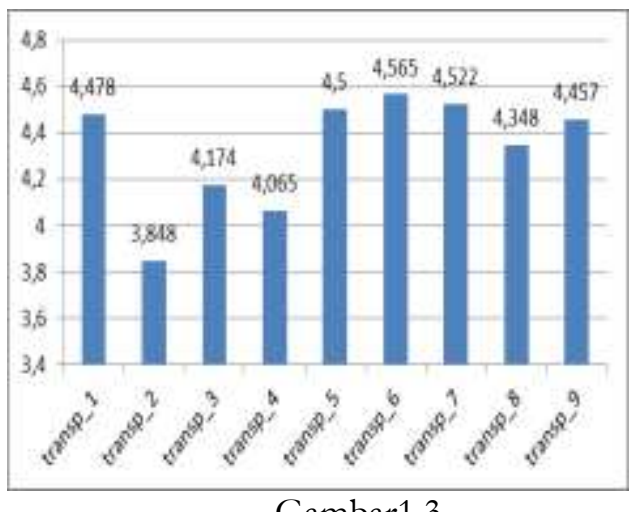

Gambar1.3

Transparansi Pengelolaan BOS Kota Blitar Akuntabilitas

Akuntabilitas berada pada level sangat akuntabel. Hal ini ditunjukkan dengan perolehan skor rata-rata tanggapan responden terhadap variabel ini sebesar 4,317 dimana nilai rata-rata ini berada diantara 4,20 - 5,00. Meskipun demikian, data juga menunjukkan adanya beberapa indikator yang berada pada posisi lebih rendah dari nilai rata-rata keseluruhan variabel ini.

Responden memberikan tanggapan bahwa terkait dengan pergeseran anggaran atau rubah rincian tidak sering terjadi, pengumuman pelaksanaan anggaran dimuat dalam laman / web sekolah, sekolah tidak melaksanakan kegiatan yang dibiayai oleh bos yang dapat dikategorikan korupsi, kolusi dan nepostime, masing-masing secara berurutan mendapatkan nilai rata-rata sebesar 4.174, 4.174, dan 4.0413. Gambaran nilai rata-rata pada variabel ini digambarkan dalam diagram sebagai berikut.

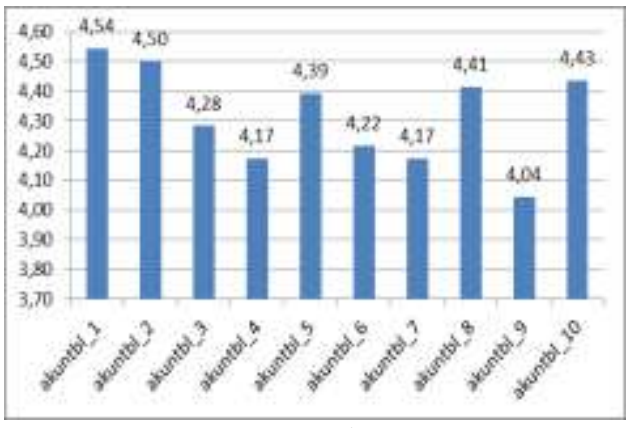

Gambar1.4

Akuntabilitas Pengelolaan BOS Kota Blitar Pengujian Regresi Berganda 
Tahapan untuk mencari pengaruh antara variabel independen dan variabel dependen, hasil regresi dapat dilihatcoefficients. Variabel bebasnya pada regresi ini adalahpartisipasi, transparansi dan akuntablitas sedangkan variabel terikatnya adalahefektivitas pengelolaan dana bantuan operasional sekolah. Output software spss yang dihasilkan adalah sebagai berikut.

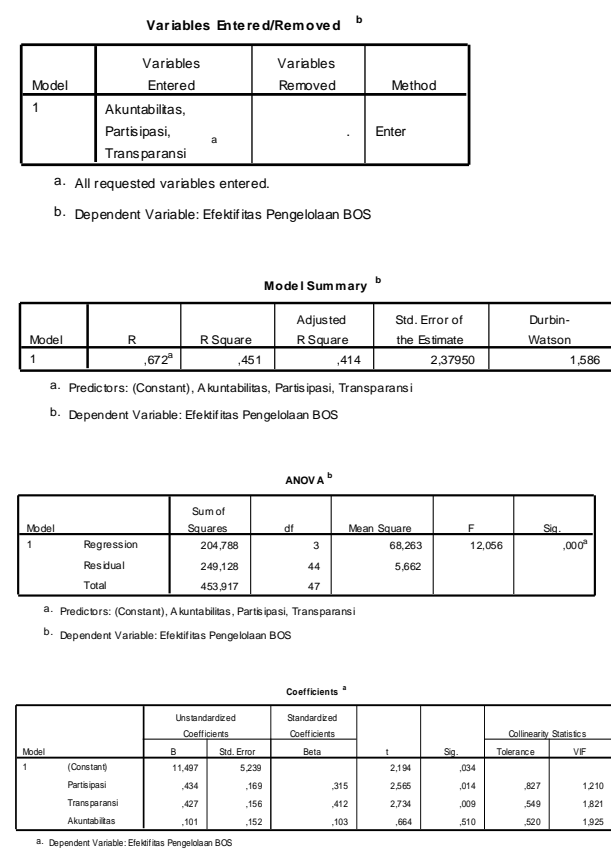

Gambar 1.5

Output SSPS Analisis Regresi Pengaruh Good School Governance Terhadap Efektifitas Pengelolaan BOS

Berdasarkan ouput tersebut didapatkan data nilai $\mathrm{F}$ hitung $=12.056$, Sig $\mathrm{F}=0.000$. Selain itu didapat juga nilai $\mathrm{R}$ Square sebesar 0.451 dan nilai beta unstandardized untuk konstata 11.497, koefesien beta variabel partisipasi (X1) 0.434 dengan nilai signifikansi 0.014 , variabel transparansi (X2) 0.427dengan nilai signifikansi 0.009 , dan variabel akuntabilitas (X3) 0.101 dengan nilai signifikansi 0,510.

\section{PEMBAHASAN}

\section{Pengaruh Partisipasi Terhadap Efektivitas Pengelolaan Bantuan Operasional Sekolah}

Hasil pengujian hipotesis penelitian ini menunjukkan bahwa $\mathrm{Ho}$ diterima atau $\mathrm{Ha}$ ditolak. Artinya terdapat pengaruh patisipasi terhadap efektivitas Pengelolaan Dana Bantuan Operasional Sekolah Dasar Kota Blitar. Selan itu, hasil perhitungan koefesien regresi untuk variabel partisipasi memiliki nilai yang positif. Fenomena mengandung pengertian bila partisipasi ditingkatkan, maka akan mening-katkan tingkat efektivitas. Demikian pula sebaliknya apabila nilai partipasi menurun, maka akan menurunkan tingkat efektivitas Pengelolaan Dana Bantuan Operasional Sekolah Dasar Kota Blitar.

Hal ini selaras dengan yang disampaikan oleh Kaiatu (2016) yang menjelaskan bahwa manajemen untuk bertindak dengan sebaik-baiknya bagi kepentingan publik maupun stakeholder. Hal ini mengandung pengertian bahwa untuk mengetahui kebutuhan publik dan stakeholder, pelibatan mereka dalam pengelolaan dana bantuan operasional sekolah mutlak diperlukan. Manajemen sekolah tidak akan mampu memenuhi kebutuhan stakeholder bila tidak menanyakan langsung kepada mereka.

Selain hal tersebut, Slamet (2006) menjelaskan bahwa partisipasi adalah proses dimana stakeholders (warga sekolah dan masyarakat) terlibat aktif baik secara individual maupun kolektif secara langsung maupun tidak langsung dalam pengambilan keputusan, pembuatan kebijakan, perencanaan, pelaksanaan, pengawasan atau pengevaluasian pendidikan sekolah.

Secara nyata berdasarkan apa yang disampaikan oleh Adi Tjahjono dalam wawancara melalui telepon menjelaskan bahwa peran komite sekolah sangat menentukan dalam pengelolaan sekolah bahkan untuk melaksanakan evaluasi diri sekolah, manajemen sekolah maupun pemetaan mutu pendidikan memerlukan jugment/penilaian dari mereka juga. Peran komite sekolah telah diatur dalam Peraturan Menteri Pendidikan dan Keudayaan Nomor 75 Tahun 2016 tentang Komite Sekolah.

Hasil analisa deskriptif menunjukkan bahwa tingkat efektivitas pengelolaan bos 
pada level sangat efektif sehingga mendukung hasil penelitian Bhawa, dkk (2014) yang menyatakan bahwa pengelolaan dana bantuan operasional sekolah berada pada kisaran sangat efektif dengan prosentase indikator perencanaan dengan kriteria sangat efektif $(91 \%)$, indikator pelaksanaan dengan kriteria sangat efektif (81\%), dan indikator pertangunggjawaban dengan kriteria sangat efektif $(88 \%)$.

\section{Pengaruh Transparansi Terhadap Efektvitas Pengelolaan Bantuan Operasional Sekolah}

Wikipedia (2016) menerang-kan bahwa transparansi memilikiartiseperti yang digunakan dalam istilah politik berarti keterbukaan dan pertanggung-jawaban. Selain itu, Slamet (2006) menjelaskan bahwa transparansi adalah keadaan dimana setiap orang yang terkait dengan kepentingan pendidikan dapat mengetahui proses dan hasil pengambilan keputusan dan kebijakan sekolah. Transparansi ini ditunjukkan dalam semua kegiatan yang dilakukan sekolah yaitu meliputi pengambilan keputusan, perencanaan dan pelaksanaan kegiatan, penggunaan uang, dan sebagainya.

Basis teori tersebut memper-kuat hasil penelitian/ pengujian terhadap hipotesis ini yang menyatakan bahwa menolak Ho dan menerima Ha. Artinya transparansi berpengaruh terhadap Efektvitas Pengelolaan Bantuan Operasional Sekolah sekaligus intepretasi ter-hadap koefesien regresi yang menyatakan apabila transparansi ditingkatkan, maka akan meningkatkan tingkat efektivitas pengelolaan dana bantuan operasional sekolah dasar. Demikian pula sebaliknya apabila transparansi menurun, maka akan menurunkan efektivitas pengelolaan dana bantuan operasional sekolah dasar.

Hasil penelitian ini juga mendukung penelitian terdahulu yang dilaksanakan oleh Fauzan (2014) yang menyatakan bahwa transparansi berpengaruh secara positif dan signifikan terhadap pengelolaan dana BOS. Bila dilihat lebih jauh, pada analisa deskriptif ditemukan bahwa umumnya responden berada pada level sangat transparan dan transparan seba-gaimana disampaikan oleh Krina P. (2003) yang mendefinisikan transpa- ransi sebagai prinsip yang menjamin akses atau kebebasan bagi setiap orang untuk memperoleh informasi tentang penyelenggaraan pemerintah-an, yakni informasi tentang kebijakan, proses pembuatan dan pelaksanaannya, serta hasilhasil yang dicapai.

\section{Pengaruh Akuntabilitas Terhadap Efektvitas Pengelolaan Bantuan Operasional Sekolah}

Hasilpenelitiantidak

mendukunghipotesisyang diajukan oleh peneliti

dimanapadapengujianinibesarnyat ${ }_{\text {hitung }}$ sebesar 0,664.Nilaiinilebihkecildarit tabel $\quad 2,013$ $(0,664<2,013)$

dengantingkatsignifikansisebesar $\quad 0,510$ lebihbesardaripada 0,05maka, inimenunjukkanbahwaHo diterimaatau $\mathrm{Ha}$ ditolak.

Artinyatidakterdapatpengaruhakuntabilitaster hadapefektivitasPengelolaan Dana BantuanOperasionalSekolahDasar Kota Blitar.Namun, nilai yang positifpadakoefesiensebesar0,101

mengandung pengertina apabila akuntabilitas ditingkatkan, maka akan meningkatkan tingkat efekti-vitas pengelolaan dana bantuan operasional sekolah dasar sebesar 0,101 point. Demikian pula sebaliknya apabilanilai akuntabilitas menurun, maka akan menurunkanefektivitas pengelolaan dana bantuan operasional sekolah dasar sebesar 0,101 point.

Hasil penelitian ini mengu-atkan hasil penelitian terdahulu yang dilaksanakan oleh Fauzan (2014) yang menyatakan bahwa akuntabi-litas berpengaruh negatif dan tidak signifikan terhadap pengelolaan dana bantuan operasional sekolah dasar kota blitar. Analisa deskriptif terhadap variabel ini yang menyatakan bahwa keseluruhan bendahara bantuan operasional sekolah dasar dirangkap oleh guru seolah-olah mengkonfirmasi hasil penelitian ini. Terkait dengan hal ini, disampaikan oleh Adi Tjahjono bahwa dengan dirangkap oleh guru kerja bendahara menjadi tidak maksimal.

Pengaruh

Bersama

Partisipasi,Transparansi, dan

Akuntabilitas Terhadap Efektvitas

Pengelolaan Bantuan Operasional Sekolah 
Hasil penelitian yang dilakukan mendukung hipotesis yang diajukan dengan ditolaknya Ho dan diteri-manya Ha. Pada pengujian ini besarnya $F_{\text {hitung }}$ sebesar12,056. Nilai ini lebih besar dari $\mathrm{F}_{\text {tabel }} 2,810(12,056$. $>\quad 2,810), \quad$ derajatsignifikansiadalah 0,000lebihkecil dari 0,05halini menunjukkan bahwa Ho ditolak atau Ha diterima. Artinya terdapat pengaruh partisipasi, transparansi dan akuntabiltas secara bersama-sama terhadap efektivitas Pengelolaan Dana Bantuan Opera-sional Sekolah Dasar Kota Blitar.

Berdasarkan model summary yang didapatkan dari hasil SPSS menunjukkan bahwa koefesien $\mathrm{r} 2=0,451$ hal ini menunjukkan bahwa 45,10 \% efektivitas pengelolaan dana bantuan operasional sekolah dasar kota blitar dipengaruhi oleh partisi-pasi, transparansi, dan akuntabilitas. Sedangkan 54,90\% dipengaruhi oleh faktor lain yang tidak diteliti sebagaimana dijelaskan Ketua Kelompok Kerja Kepala Sekolah Dasar (K3SD) Kota Blitar, Sdr. M. Toifudin bahwa sebenarnya kondisi bendahara yang ada di sekolah memerlukan pelatihan khusus untuk meningkatkan kompetensi yang dimiliki terkait dengan perbendaha-raan bantuan operasional sekolah.

\section{KESIMPULAN}

Berdasarkan analisa dan uji hipotesis yang telah dipaparkan sebelumnya, peneliti dapat menarik kesimpulan bahwa partisipasi stakeholder berpengaruh positif dan signifikan terhadap efektivitas pengelolaan dana bantuan operasi-onal sekolah dasar di Kota Blitar, transparansi berpengaruh positif dan signifikan terhadap efektivitas pengelolaan dana bantuan operasional sekolah dasar di Kota Blitar, akuntabilitas tidak berpengaruh positif dan signifikan terhadap efektivitas pengelolaan dana bantuan operasional sekolah dasar di Kota Blitar. Selain itu, . disimpulkan juga bahwa secara bersama-sama partisipasi stakeholder, transparansi, dan akuntabilitas berpengaruh positif dan signifikan terhadap efektivitas pengelolaan dana bantuan operasional sekolah dasar di Kota Blitar

\section{REKOMENDASI}

Peneliti memberikan rekomendasi sekolah perlu mening-katkan efektivitas pengelolaan dana bantuan operasional sekolah dengan meningkatkan kualitas laporan realisasi kegiatan agar tepat waktu dan tidak molor, serta sesuai dengan peruntukkannya selain itu tidak melakukan markup harga / anggaran dalam laporan realisasi bantuan operasional sekolah. Selain itu, pengelola dana bantuan operasional sekolah diharapkan selalu mening-katkan partisipasi, transparansi, dan akuntablitas guna meningkatkan efektivitas pengelolaan dana bantuan operasional sekolah dengan menge-lola sumbangan wali murid bila biaya dari bantuan operasional sekolah tidak mencukupi dengan baik dan melaksanakan survey/angket kepada pihak-pihak terkait tentang rencana dan program yang akan dituangkan dalam RAPBS, meningkatkan arus informasi melalui kerjasama dengan media massa, mempermuda stakeholder memiliki akses informasi baik orang tua maupun lembaga non pemerintah, serta menyusun suatu mekanisme pengaduan jika ada peraturan yang dilanggar atau permintaan untuk membayar uang suap mengusahakan tidak sering melaksanakan pergeseran anggaran atau rubah rincian, membuatu pengumuman pelaksanaan anggaran dimuat dalam laman / web sekolah, serta tidak melaksanakan kegiatan yang dibiayai oleh bos yang dapat dikategorikan korupsi, kolusi dan nepostime

Dinas Pendidikan Kota Blitar sebagai tim manajemen bantuan oprasional sekolah ditingkat kota seharusnya memperhatikan benda-hara bantuan operasiona sekolah dari sisi kesejahteraan, pendidikan dan pelatihan, pemenuhan tenaga sehingga tidak dirangkap oleh guru maupun jabatan lainnya.

\section{DAFTAR RUJUKAN}

Bantuan Operasional Sekolah (BOS) Pada Sekolah Dasar di Kecamatan Sukasada". Vol. 4, No. 1, hlm: 1-11.

Direktorat Jenderal Manajemen Pendidikan Dasar dan Menengah.(2009). BukuPanduan Bantuan Operasional Sekolah (BOS) untuk Pendidikan Gratis dalam Rangka Wajib Belajar 9 Tahun. Jakarta: Depdiknas. 
Fauzan. (2014). "Pengaruh Penerapan Good Corporate Governance Terhadap Perilaku Etis dalam Pengelolaan Dana Bantuan Operasional Sekolah". Jurnal Modernisasi , Vol. 10, No. 3, hlm: 158-169.

Ghozali,I. (2008). Structural Equation Modeling Metode Alternatif denganPartial Least Squar. Semarang: BP Undip.

Gramedia Pustaka Utama.

Halim, A. (2001). Manajemen Keuangan Daerah. Yogyakarta: UPP AMP YKPN.

Handayaningrat, S. (1994). Pengantar Studi Ilmu Administrasi dan Manajemen.

Hariswati,N. (2015). "Analisa Akuntabilitas dan Transparansi Tentang Implementasi Kebijakan Pengelolaan BOS". Jurnal Ekonomika Bisnis, Vol. 6, No. 1, hlm: 75-88.

Haryanto. (2007). Akuntansi Sektor Publik. Semarang: BP Undip.

Helena, \& Therese. (2005). Stewardship Theory. Harkes Ingvild.

Indriantoro \& B. Supomo. (2002). Metodologi Penelitian Bisnis untuk. Akuntansi

Jakarta: CV Haji Masagung.

Jersey: John Wiley \& Sons Inc.

Kaen, F. R. (2003). A Blueprint for Corporate Governance: Stregy, Accountability, and the Preservation of Shareholder Value. USA:Amacom.

Kaihatu,T. S. (2006). "Good Corporate Governance dan Penerapannya di Indonesia". Jurnal Manajemen dan Kewirausahaan, Vol.8, No.1, hlm:19.

Kurniawan, A. (2005). Transformasi Pelayanan Publik. Yogyakarta: Pembaruan.
Martono, N. (2011). Metode Penelitian Kuantitatif: Analisis Isi dan Analisis Data

Monks, R. A., \& Minow, N. (2003). Corporate Governance 3rd Edition.

PeraturanMenteri Pendidikan dan Kebudayaan Republik Indonesia. (2015). Nomor 80 Tahun 2015 tentang Petunjuk Teknis Penggunaan danPertanggungjawaban Keuangan

Dana Bantuan Operasional Sekolah untuk Sekolah Dasar dan Sekolah Menengah Pertama. Jakarta:Kemendikbud.

PeraturanPemerintah. (2005). PP Nomor 19 Tahun 2005 tentang StandarNasional Pendidikan.

Peraturan Pemerintah. (2008). PP Nomor 48 Tahun 2008 tentang PendanaanPendidikan.

Regina, B., Soeaidy, S., \& Ribawanto, H. (2015). "Implementasi Kebijakan Bantuan Operasional Sekolah di Kota Malang". Jurnal AdministrasiPublik, Vol. 3, No. 1, hlm: 61-66.

Sekunder. Jakarta: Raja Grafindo Persada.

Shaw, J. C. (2003). Corporate Governance and Risk: A System Approach. New

Simamora, B. (2004). Riset Pemasaran Falsafah, Teori dan Aplikasi. Jakarta. PT.

Slamet, P. H. (2006). Manajemen Berbasis Sekaolah: Partisipasi, Transparansi,

Subagyo, A. W. (2000). Efektivitas Program Penanggulangan Kemiskinan dalamPemberdayaan Masyarakat Pedesaan. Yogyakarta: UGM.

Sugiyono. (2011). Metode Penelitian Kuantitatif Kualitatif dan R\&D Cetakan Ke

Sugiyono. (2012). Metode Penelitian Bisnis Pendekatan Kuantitatif, Kualitatifdan RerD) Cetakan Ke 16. Bandung: Alfabeta. 
Tarigan, J. 2008. "User Satisfaction using WebQual Instrument : A Research on Stock Exchange of Thailand (SET)". Jurnal Akuntansi dan Keuangan, Vol. 10, No. 1, hlm: 3447.

Trismanto\& Z.A. Adiwijaya. (2012). "Tata Kelola Sekolah RSBI serta Dampaknya Terhadap Kepuasan dan Loyalitas Masyarakat". JurnalPendidikan Ekonomi Dinamika Pendidikan, Vol. 7, No. 2, hlm: 1-14.

Ulum, I. M. (2008). Akuntansi Sektor Publik. Malang: UMM Press.

Undang-Undang Dasar 1945 Pasal 31 ayat 4 tentang Hak dan Kewrajiban Negara.

Undang-Undang. (2003). UU Nomor 20 Tahun 2003 tentang Sistem PendidikanNasional.

Wahyuni, K. A. (2014). "Efektivitas Rencana Kegiatan dan Anggaran Sekolah (RKAS) pada Kualitas Layanan Pendidikan SMK dan SMA di Kecamatan Sawan Tahun Ajaran 2013/2014". Vol. 4, No. 1, hlm: 111.

Yahya, A. A. (2013). "Kajian Dana Pendidikan Bantuan Operasional Sekolah (BOS) dan Sekolah Gratis (Kasus di Wilayah Kecamatan Blimbing Kota Malang)". Jurnal Ilmiah, Vol. 1, No. 2, hlm: 1-22. 